\title{
The ability of probiotics to ameliorate blood and gonad damage caused by copper toxicity in Nile tilapia (Oreochromis niloticus)
}

\author{
Alfiah Hayati(D), Manikya Pramudya(iD and Hari Soepriandono (D) \\ Department of Biology, Faculty of Science and Technology, Universitas Airlangga, Campus C, Mulyorejo, \\ Surabaya, Indonesia. \\ Corresponding author: Alfiah Hayati, e-mail: alfiah-h@fst.unair.ac.id \\ Co-authors: MP: manikya.pramudya@fst.unair.ac.id, HS: hari-s@fst.unair.ac.id \\ Received: 24-07-2021, Accepted: 11-10-2021, Published online: 25-11-2021
}

doi: www.doi.org/10.14202/vetworld.2021.2964-2970 How to cite this article: Hayati A, Pramudya M, Soepriandono H (2021) The Ability of probiotics to ameliorate blood and gonad damage caused by copper toxicity in Nile tilapia (Oreochromis niloticus), Veterinary World, 14(11): 2964-2970.

\begin{abstract}
Background and Aim: Industrial waste, such as heavy metals, is a major source of water pollution; at high levels, such pollution can reduce river water quality to the extent that it becomes unsuitable for aquaculture of freshwater fish. This study aimed to focus on the effects of copper $(\mathrm{Cu})$ exposure in Nile tilapia (Oreochromis niloticus) and specifically the ability of Lactobacillus-based probiotics supplementation in fish feed to ameliorate damage to gonads and negative effects on red blood cells (RBCs), whole blood cells (WBCs), hematocrit (HCT) levels, hemoglobin (HGB) levels, and malondialdehyde (MDA) levels following such exposure.
\end{abstract}

Materials and Methods: Thirty-two Nile tilapia fish were divided into eight groups: A negative control (without probiotics or $\mathrm{Cu}$ ), a positive control (with probiotics but without $\mathrm{Cu}$ ), three treatments with probiotics in feed, and one of three $\mathrm{Cu}$ concentrations $(0.75,1.50$, or $3.00 \mathrm{mg} / \mathrm{L})$, and three treatments with these three $\mathrm{Cu}$ concentrations but without probiotics in feed. The probiotics concentration in feed was $25 \mathrm{~mL} / \mathrm{kg}\left(1 \times 10^{8} \mathrm{CFU} / \mathrm{mL}\right)$. Feeding was for 15 days, after which the hematological parameters, gonadal (testis) structure, and MDA levels of fish were analyzed.

Results: Exposure to $\mathrm{Cu}$ significantly $(\mathrm{p}<0.05)$ affected fish hematology (decreased HGB, HCT, RBC, and WBC levels) and altered the structure of the testes. However, the addition of probiotics to fish feed significantly $(\mathrm{p}<0.05)$ ameliorated these effects on hematology and maintained the histological structure of the gonads.

Conclusion: $\mathrm{Cu}$ exposure at $\geq 1.5 \mathrm{mg} / \mathrm{L}$ affected the hematologic parameters, gonadosomatic index, MDA levels, and testicular cells and tissue of Nile tilapia. However, probiotics supplementation in fish feed helped ameliorate the negative effects of $\mathrm{Cu}$ on these parameters. Thus, the Lactobacillus-based probiotics used in this study were apparently able to neutralize $\mathrm{Cu}$ toxicity in Nile tilapia.

Keywords: copper, fisheries, fresh water, hematology, probiotics, testis structure.

\section{Introduction}

Freshwater aquaculture is generally conducted in rivers, ponds, lakes, reservoirs, or other water sources. Household waste resulting from human activities is a major source of pollution to such water sources; indeed, such pollution can alter the quality of river water to the extent that it is not suitable for use in aquaculture. Industrial waste, including that containing heavy metals such as copper $(\mathrm{Cu})$, imposes an additional burden on river water quality and poses serious health risks [1,2].

Because heavy metals are not easily degraded, they are typically excreted together with feces and urine by fish. Consequently, fish are often used as indicators of heavy metal pollution in aquatic ecosystems; furthermore, heavy metals can be bioaccumulated

Copyright: Hayati, et al. Open Access. This article is distributed under the terms of the Creative Commons Attribution 4.0 International License (http://creativecommons.org/licenses/by/4.0/), which permits unrestricted use, distribution, and reproduction in any medium, provided you give appropriate credit to the original author(s) and the source, provide a link to the Creative Commons license, and indicate if changes were made. The Creative Commons Public Domain Dedication waiver (http://creativecommons.org/ publicdomain/zero/1.0/) applies to the data made available in this article, unless otherwise stated. and biomagnified through the food chain [3]. Heavy metals can enter the bodies of fish through the gills, body surface, or digestive tract [4]. After absorption, the metal is transported through the bloodstream to the organs and tissues where it accumulates. Heavy metals in the blood can cause blood abnormalities, thrombotic lesions, and necrotic cells. They can potentially increase reactive oxygen species (ROS) in endothelial cells, which affects the survival of fish. Increased oxidation can also alter blood glucose levels, protein concentrations, and hematological parameters, thereby leading to increased mortality. Furthermore, lipid oxidation reduces membrane integrity and DNA oxidation, which results in DNA fragmentation. The accumulation of heavy metals in the gonads of fish causes necrosis of the epithelium of seminiferous tubules and reduces sperm viability $[5,6]$.

The World Health Organization defines probiotics as living microorganisms that provide host health benefits when the quantity consumed is sufficient [7]. The use of probiotics to control disease and improve water quality is prevalent in the aquaculture industry. LAB can reportedly remove heavy metals [8] by binding to cationic heavy metals that depend on $\mathrm{pH}$; the $\mathrm{pH}$ 
effect arises due to competition for negatively charged binding between cationic metals and protons. Heavy metals are also removed due to microbes producing extracellular molecules known as siderophores, which have a high affinity for iron and can form complexes with other metals, even those with lower affinities. Siderophore-metal complexes can reduce metal concentrations and produce biosurfactant compounds that increase the solubility of heavy metals and thereby reduce their toxicity to cells [9].

Nile tilapias (Oreochromis niloticus) are sensitive to environmental changes and have been used as bioindicators of toxicity parameters [10]. In Indonesia, many studies have been conducted to analyze the effects of heavy metals on the physiology of Nile tilapia. However, few studies have reported the effects of probiotics on fish exposed to heavy metals, especially those exposed to $\mathrm{Cu}$. Therefore, this study aimed to analyze the ability of probiotics supplementation in fish feed to ameliorate $\mathrm{Cu}$ exposure-induced gonad damage and the negative effects of $\mathrm{Cu}$ on the red blood cells (RBCs), whole blood cells (WBCs), hematocrit (HCT) levels, hemoglobin (HGB) levels, and malondialdehyde (MDA) levels of Nile tilapia.

\section{Materials and Methods}

\section{Ethical approval}

All procedures involving animal care were performed according to internationally recognized guidelines for the ethical use of animals [11] and Animal Care and Use Committee of Veterinary Faculty, Universitas Airlangga, Surabaya, Indonesia. Before being sacrificed, fish were made unconscious in $0.1 \mathrm{~mL} / \mathrm{L}$ of clove oil containing eugenol. Clove oil solution was used to soothe the fish for several minutes without rejection reaction in fish [11].

\section{Study period and location}

The study was conducted from May 2019 to March 2020. EThe experimental study was conducted in Animal Laboratory, Department of Biology, Faculty of Science and Technology, Universitas Airlangga.

\section{Probiotics for fish diet}

The probiotics used in this study consisted of Lactobacillus buchneri (DSM 20057), Lactobacillus casei (DSM 20011), Lactobacillus bulgaricus (NBRC13953), and Lactobacillus fermentum (ME3) in an equal ratio of 1:1:1:1. Each bacterial strain was cultured in de Man, Rosaga, and Sharpe broth for $24 \mathrm{~h}$ at $37^{\circ} \mathrm{C}$. Subsequently, the culture broth from the four strains was mixed and centrifuged at $8000 \mathrm{~g}$ and $4^{\circ} \mathrm{C}$ for $15 \mathrm{~min}$ to precipitate the cells. Bacterial cells were then diluted using phosphate-buffered saline (PBS, pH 7.4) at a final concentration of $1 \times 10^{8} \mathrm{CFU} / \mathrm{mL}$. This concentration of probiotics was sprayed at approximately $25 \mathrm{~mL} / \mathrm{kg}$ onto fish feed, which was then allowed air dry.

\section{Animals}

Thirty-two male Nile tilapia (age: 4-5 months) in a healthy condition (weight: $200 \pm 20 \mathrm{~g}$ ) with mature gonads was obtained from Pandaan Aquaculture Management Unit, Ministry of Fisheries, East Java Province, Indonesia. The fish were initially fed commercial pellets $(30 \%$ protein, $3 \%$ fat, and $4 \%$ fiber; Takari, Sidoarjo, Indonesia) for 2 weeks of acclimation and kept in a glass rectangular tank $(90 \mathrm{~cm} \times 60 \mathrm{~cm} \times 50 \mathrm{~cm})$ utilized for fish-rearing. A 12-h light and 12-h dark photoperiod was used, and the $\mathrm{pH}$ range of the water was $7.5 \pm 0.03$. An aquarium pump (Aquatic Pump Type WP-4880; $45 \mathrm{~W}$ ) was positioned inside each rearing tank at the corner to recycle the water [12]. The freshwater was aerated at $25^{\circ} \mathrm{C} \pm 1.5^{\circ} \mathrm{C}$ for 2 weeks of acclimation. The experimental feeding period was 15 days. During this period, the fish were fed with the experimental diets at $2 \%$ of their body weight twice daily at 7:00 am and 4:00 pm.

\section{Animal experiment}

The 32 Nile tilapia was divided into eight groups: Two control groups, a negative control without probiotics or $\mathrm{Cu}$ and a positive control with probiotics but without $\mathrm{Cu}$ (negative control fish were kept in $\mathrm{Cu}$-free water and fed the basal diet; positive control fish were kept in $\mathrm{Cu}$-free water and fed the probiotics-supplemented diet), and six treatment groups exposed to $\mathrm{Cu}$ at one of three concentrations $(0.75,1.50$, and $3.00 \mathrm{mg} / \mathrm{L}$ ) that were fed with either the basal diet or the probiotics-supplemented diet. The concentration range for $\mathrm{Cu}$ exposure was chosen based on the $\mathrm{LC}_{50}$ value for $\mathrm{Cu}$ reported in a previous study [13]. All treatments were administered for 15 days.

\section{Fish hematology}

Blood (1.0-1.5 mL) was collected using a disposable syringe $(3 \mathrm{~mL})$ from the caudal artery of Nile tilapia and then transferred to a special tube containing potassium ethylenediaminetetraacetic acid. At no more than $3 \mathrm{~h}$ after the blood sample was taken, hematological parameters were measured. Coulter counters (CELL DYN 1700) were used to calculate WBC, RBC, HGB, and HCT levels.

\section{Gonadosomatic index (GSI) estimation}

An electronic balance was used to determine the total weight $(\mathrm{g})$ of each fish specimen. The gonads were dissected and also weighed $(\mathrm{g})$ to the nearest $0.01 \mathrm{mg}$. The GSI was calculated using the following formula:

$$
\begin{aligned}
\text { GSI }= & \text { Weight of gonad } \times 100 \\
& \text { Weight of fish. }
\end{aligned}
$$

\section{Cu determination in the gonads}

Fish samples were rinsed with distilled water and dissected to separate the gonad using stainless steel instrument. 1One g of sample was crushed with perchloric acid and nitric acid with 1:1 in ratio, followed by sulfuric acid. The mixture was heated at $200^{\circ} \mathrm{C}$ for 30 minutes. Then, it was cooled to room temperature $\left(25-28^{\circ} \mathrm{C}\right)$ and made to a scale of $50 \mathrm{~mL}$ with distilled water. $\mathrm{Cu}$ level was analyzed using ZEEnit $700 \mathrm{P}$ atomic absorption spectrophotometer (AAS; flame 
and graphite furnace AAS systems, Analytik Jena, Germany) equipped with deuterium and Zeeman background correction, respectively, as recommended by the manufacturer. Detection limits were $0.046 \mu \mathrm{g} / \mathrm{L}$ for the flame AAS and $0.002 \mu \mathrm{g} / \mathrm{L}$ for the graphite furnace AAS.

\section{Determination of MDA in the gonads}

Small pieces of gonad suspension were added to $300 \mathrm{~mL}$ of ice-cold PBS and homogenized on ice for $20 \mathrm{~s}$ using sonication. MDA concentration was then analyzed using a QuantiChrom TBARS Assay Kit (DTBA-100; BioAssay Systems, USA). The absorbance was measured at $535 \mathrm{~nm}$.

\section{Histology of the gonads}

Testes were fixed in Bouin's solution for $24 \mathrm{~h}$. The tissues were then dehydrated in an ascending series of alcohol, cleared in xylene, and finally embedded in paraffin wax. Sections (4-6 $\mu \mathrm{m}$ thick) were cut, processed, and stained with hematoxylin and eosin. They were examined under a light microscope (Olympus, Japan) and photographed using a built-in camera.

\section{Statistical analysis}

All data related to hematological parameters and metal concentration levels are given as means \pm standard error. These data were tested using a factorial $2 \times 4$ (two levels of antibiotics and two levels of $\mathrm{Cu}$ ) analysis of variance through the statistical package for the social sciences software package (IBM, United StatesNY, USA). Before this analysis, the normality and homogeneity of the data were confirmed. Means were subsequently compared using Fisher's protected least significant difference test. Values were considered statistically significant at $\mathrm{p}<0.05$.

\section{Results}

\section{Hematological parameters}

Table-1 shows the effects of $\mathrm{Cu}$ concentrations on the HBG levels of fish with and without probiotic supplements. At all $\mathrm{Cu}$ exposures $(0.75,1.50$, and $3.00 \mathrm{mg} / \mathrm{L}$ ), either with or without probiotics, HGB levels were significantly decreased comparedd to the $\mathrm{Cu}$-free controls $(\mathrm{p}<0.005)$. However, probiotics supplementation in the positive control group increased HGB levels compared with those in the negative control group (from $9.0 \pm 0.2$ to $10.8 \pm 1.0 \mathrm{~g} / \mathrm{dL}$ ). Similarly, all $\mathrm{Cu}$ exposure treatments showed a significant increase in HGB with probiotics supplementation $(p<0.05)$. In contrast, there was no significant difference ( $p>0.05$ ) among HGB levels in $\mathrm{Cu}$ exposure groups across concentrations in groups with or without probiotics supplementation.

Probiotics supplementation also increased HCT levels; the negative control group had $27.5 \% \pm 0.7 \%$ HCT, whereas the positive control group (with probiotics) had $31 \% \pm 2.0 \%$ HCT. $\mathrm{Cu}$ exposure significantly reduced HCT levels with and without the probiotics supplement $(\mathrm{p}<0.05)$. However, the HCT percentage was higher in groups exposed to $\mathrm{Cu}$ concentrations and administrated probiotics than it was in $\mathrm{Cu}$-exposed fish that were not administrated the probiotics supplement.

There was no significant difference between the RBC levels of the control group administrated with probiotics $\left(2.4 \pm 0.410^{6} / \mathrm{mm}^{3}\right)$ and those of the group not administrated with probiotics $\left(2.0 \pm 0.0510^{6} / \mathrm{mm}^{3}\right)$. Exposure to $0.75 \mathrm{mg} / \mathrm{L} \mathrm{Cu}$ did not affect RBC levels, but $\mathrm{Cu}$ at 1.50 and $3.00 \mathrm{mg} / \mathrm{L}$ reduced $\mathrm{RBC}$ count significantly $(\mathrm{p}<0.05)$. However, in these $\mathrm{Cu}$-exposed groups, probiotic administration significantly $(\mathrm{p}<0.05)$ improved RBC levels.

Similarly, there was no significant difference ( $p>0.05$ ) between the WBC levels of the control group administrated with probiotics $\left(129 \pm 310^{3} / \mathrm{mm}^{3}\right)$ and those of the group not administrated with probiotics $\left(137 \pm 710^{3} / \mathrm{mm}^{3}\right)$. However, the WBC count of fish decreased significantly $(\mathrm{p}<0.05)$ after exposure to $\mathrm{Cu}$, probiotics supplementation could not significantly increase $\mathrm{WBC}$ counts in $\mathrm{Cu}$-exposed fish at any $\mathrm{Cu}$ concentration $(\mathrm{p}>0.05)$.

\section{GSI analysis}

The GSI of Nile tilapia exposed to $\mathrm{Cu}$ and those fed probiotics supplements are shown as index values in Table-2. The GSI of these fish was 1.08$1.33 \%$. Without probiotics, there was no significant difference $(p>0.05)$ in the GSI of fish exposed to $0.75 \mathrm{mg} / \mathrm{L} \mathrm{Cu}$ and those in the control group, which shows that this $\mathrm{Cu}$ exposure level did not affect the gonadal development of the fish. However, the significant decreases $(\mathrm{p}<0.05)$ in GSI according to $\mathrm{Cu}$ concentration, $1.30 \%, 1.12 \%$, and $1.08 \%$ for 0.75 ,

Table-1: Effect of $\mathrm{CuSO}_{4}$ on hematology of $\mathrm{O}$. niloticus with and without probiotic supplements.

\begin{tabular}{|c|c|c|c|c|c|}
\hline $\begin{array}{l}\text { Treatments } \\
\left.\text { (CuSO }_{4} \mathrm{mg} / \mathrm{L}\right)\end{array}$ & $\begin{array}{c}\text { Probiotic }\left(1 \times 10^{8}\right. \\
\text { CFU } / \mathrm{mL})\end{array}$ & HBG (g/dL) & HCT (\%) & $\operatorname{RBC}\left(\times 10^{6} / \mathrm{mm}^{3}\right)$ & WBC $\left(\times 10^{3} / \mathrm{mm}^{3}\right)$ \\
\hline 0 & No & $9 \pm 0.2^{\mathrm{a}}$ & $27.5 \pm 0.70^{a}$ & $2 \pm 0.05^{a}$ & $137 \pm 7^{a}$ \\
\hline 0.75 & No & $7.8 \pm 0.4^{b}$ & $22.2 \pm 0.80^{b}$ & $2 \pm 0.03^{a}$ & $122 \pm 5^{b}$ \\
\hline 1.5 & No & $7.4 \pm 0.3^{b}$ & $20.2 \pm 1.20^{b}$ & $1.9 \pm 0.03^{b}$ & $120 \pm 2^{b}$ \\
\hline 3 & No & $8.5 \pm 0.2^{b}$ & $24.7 \pm 0.50^{c}$ & $1.9 \pm 0.03^{b}$ & $127 \pm 1^{b}$ \\
\hline 0 & Yes & $10.8 \pm 1.0^{c}$ & $31 \pm 2.00^{d}$ & $2.4 \pm 0.40^{\mathrm{a}}$ & $129 \pm 3^{a}$ \\
\hline 0.75 & Yes & $9.3 \pm 0.6^{a}$ & $28 \pm 1.50^{\mathrm{ad}}$ & $2.1 \pm 0.10^{\mathrm{a}}$ & $131 \pm 4^{a}$ \\
\hline 1.5 & Yes & $9.3 \pm 0.6^{a}$ & $29 \pm 2.83^{a}$ & $2.1 \pm 0.03^{a}$ & $113 \pm 4^{b}$ \\
\hline 3 & Yes & $9.9 \pm 0.2^{a}$ & $30 \pm 0.28^{a}$ & $2.1 \pm 0.03^{a}$ & $118 \pm 1^{b}$ \\
\hline
\end{tabular}

$\mathrm{RBC}=$ Red blood cells, WBC $=$ Whole blood cells, HCT=Hematocrit.

Different letters $(a, b, c)$ showed a significant difference at $p<0.05$. 
Table-2: Effect of CuSO4 on GSI, MDA, and heavy metal levels of $\mathrm{Cu}$ in the gonads of $O$. niloticus fish with and without probiotic supplements.

\begin{tabular}{|c|c|c|c|c|}
\hline Treatments $\left(\mathrm{CuSO}_{4} \mathrm{mg} / \mathrm{L}\right.$ ) & Probiotic $\left(1 \times 10^{8} \mathrm{CFU} / \mathrm{mL}\right)$ & GSI (\%) & MDA $(\mu M / m L)$ & Cu levels in gonad $(\mathrm{mg} / \mathrm{L})$ \\
\hline 0 & No & $1.33 \pm 0.03^{a}$ & $1.40 \pm 0.01^{\mathrm{a}}$ & $0.01 \pm 0.001^{\mathrm{a}}$ \\
\hline 0.75 & No & $1.30 \pm 0.08^{a}$ & $1.40 \pm 0.01^{a}$ & $0.39 \pm 0.004^{b}$ \\
\hline 1.5 & No & $1.12 \pm 0.03^{b}$ & $1.47 \pm 0.02^{b}$ & $1.08 \pm 0.002^{c}$ \\
\hline 3 & No & $1.08 \pm 0.02^{b}$ & $1.54 \pm 0.01^{c}$ & $2.46 \pm 0.03^{d}$ \\
\hline 0 & Yes & $1.98 \pm 0.10^{c}$ & $1.38 \pm 0.01^{\mathrm{d}}$ & $0.01 \pm 0.002^{\mathrm{a}}$ \\
\hline 0.75 & Yes & $1.8 \pm 0.20^{c}$ & $1.39 \pm 0.01^{\mathrm{d}}$ & $0.30 \pm 0.03^{b}$ \\
\hline 1.5 & Yes & $1.55 \pm 0.08^{c}$ & $1.38 \pm 0.01^{\mathrm{d}}$ & $0.90 \pm 0.005^{c}$ \\
\hline 3 & Yes & $1.34 \pm 0.10^{\mathrm{a}}$ & $1.42 \pm 0.01^{a}$ & $2.33 \pm 0.001^{d}$ \\
\hline
\end{tabular}

MDA=Malondialdehyde, GSI=Gonadosomatic index

Different letter $(a, b, c, d)$ showed significant difference

1.50 , and $3.00 \mathrm{mg} \mathrm{Cu} / \mathrm{L}$, respectively, showed that higher $\mathrm{Cu}$ exposures could affect spermatogenic cell development. However, with the addition of probiotic supplements, the development of fish gonads was not affected in this way when they were exposed to the range of $\mathrm{Cu}$ concentrations. Indeed, probiotic supplementation significantly protected $(p<0.05)$ the gonadal development of $\mathrm{Cu}$-exposed fish, as shown by GSI values of $1.34-1.98 \%$.

\section{Heavy metal accumulation of $\mathrm{Cu}$ in fish gonads}

In fish gonads, no significant difference $(\mathrm{p}>0.05)$ in $\mathrm{Cu}$ accumulation was observed in the negative and positive control groups. In addition, with the lowest $\mathrm{Cu}$ exposure $(0.75 \mathrm{mg} / \mathrm{L})$, there was no significant difference in $\mathrm{Cu}$ accumulation between the group administrated with probiotics and the group without probiotics. However, when $\mathrm{Cu}$ exposure was increased to 1.5 and $3 \mathrm{mg} / \mathrm{L}$, the administration of probiotics significantly reduced the accumulation of $\mathrm{Cu}$ in the fish gonads ( $\mathrm{p}<0.05$; Table-2).

\section{MDA levels in the gonads}

MDA levels in the fish gonads did not differ significantly $(p>0.05)$ in the $0.75-\mathrm{mg} / \mathrm{L} \mathrm{Cu}$ treatment groups. However, $\mathrm{Cu}$ exposure at 1.5 or $3 \mathrm{mg} / \mathrm{L}$ significantly $(\mathrm{p}<0.05)$ increased the level of MDA detected; thus, these exposures increased $\mathrm{Cu}$ oxidation stress. Nevertheless, the probiotics supplement was able to reduce MDA levels during exposure to different $\mathrm{Cu}$ concentrations. Thus, the probiotics apparently decreased oxidative stress caused by $\mathrm{Cu}$ (Table-2).

\section{Histological analysis}

Male gonads in the control group showed a typical compact architecture with characteristic cyst distribution in the seminiferous tubules. Spermatogenic cell morphology at various stages of differentiation was noted as spermatogonium $(\mathrm{Sg})$, spermatocytes $(\mathrm{Sp})$, spermatids $(\mathrm{Sd})$, and spermatozoa $(\mathrm{Sz}) . \mathrm{Sg}$ was found in cysts with various numbers of individual cells and was usually isolated near the periphery of the testes; cysts containing $\mathrm{Sp}, \mathrm{Sd}$, and $\mathrm{Sz}$ were located on the lobule wall (Figure-1a).

$\mathrm{Sg}$ and $\mathrm{Sp}$ were round with diameters of $49.5 \pm 4$ and $39.8 \pm 5 \mu \mathrm{m}$, respectively. Sd were basophilic ball
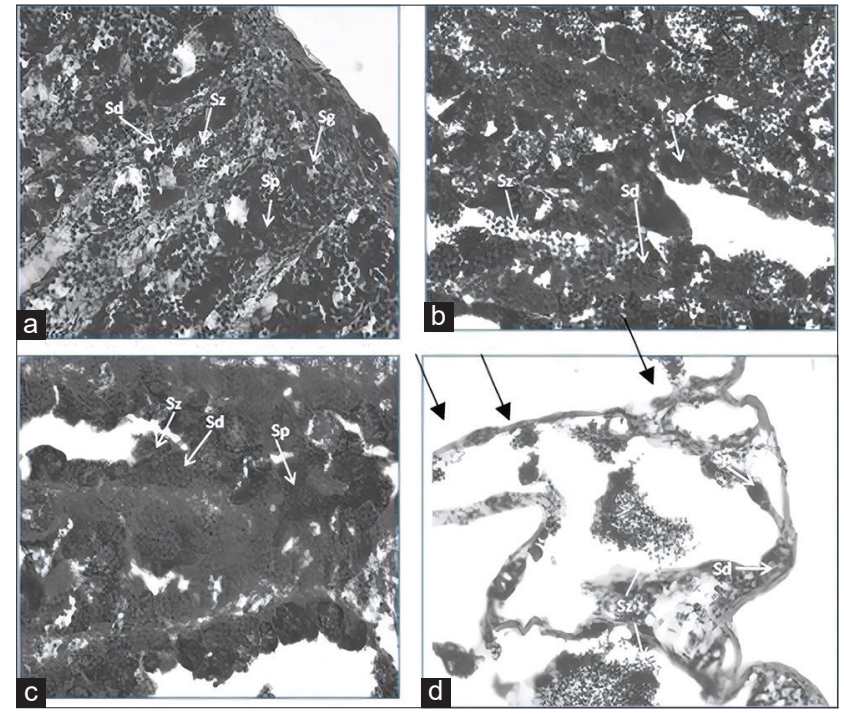

Figure-1: Levels of hemoglobin (a), percentage of hematocrit (b), red blood cells (c), and whole blood cell (d) exposed to heavy metals $\mathrm{CuSO}_{4}$. $+\mathrm{p}$ : with probiotics; $-\mathrm{p}$ : no-probiotics.

cells with a diameter of $25 \pm 3 \mu \mathrm{m}$; when they matured, they became smaller and remained in solid groups. Sz had a diameter of $16 \pm 3 \mu \mathrm{m}$ (Table-3). Testicular histological examination of fish treated with increasing concentrations of $\mathrm{Cu}$ showed dose-dependent changes in the spermatogenic cell structure in cysts. $\mathrm{Cu}$ treatment induced complete disorganization in cyst settings. Several cysts were degenerated, which affected the development of spermatogenic cells (Figure-1b). Degeneration of cysts increased after exposure to $1.5 \mathrm{mg} / \mathrm{L} \mathrm{Cu}$ (Figure-1c). Severe damage was observed with $3-\mathrm{mg} / \mathrm{L} \mathrm{Cu}$ exposure as a reduction in the number of cysts and spermatogenic cells (Figure-1d). In addition, acute testicular atrophy and vacuolated seminiferous lobules were observed.

Probiotics supplements affected the spermatogenic cells in each cyst in the lobules. Cysts appeared to be the largest in the control group, as they were filled with spermatogenic cells (Figure-1a), followed by cysts in the group exposed to $0.75 \mathrm{mg} / \mathrm{L} \mathrm{Cu}$ (Figure-1b). $\mathrm{Cu}$ exposure decreased the diameter of cysts; a major decrease was observed following exposure to 1.5 and $3 \mathrm{mg} / \mathrm{L} \mathrm{Cu}$ (Figures- $1 \mathrm{c}$ and d). 
Table-3: The diameter of fish spermatogenic cells in control.

\begin{tabular}{llc}
\hline No. & Spermatogenic cells $\mathbf{5 + p}$ & Diameter $(\boldsymbol{\mu m})$ \\
\hline 1 & Spermatogonium & $49.5 \pm 4$ \\
2 & Spermatocytes & $39.8 \pm 5$ \\
3 & Spermatids & $25 \pm 3$ \\
4 & Spermatozoa & $16 \pm 3$ \\
\hline
\end{tabular}

Spermatogenic cells protected in the cyst had various sizes depending on the treatment. The higher the $\mathrm{Cu}$ exposure level, the smaller the diameter (Figure-2). This was consistent with the structural reduction of the seminiferous tubules and cysts after exposure to $\mathrm{Cu}$. Probiotics supplements were able to ameliorate the $\mathrm{Cu}$-induced decrease in diameters (Figure-3). There was a significant difference $(p<0.05)$ in the diameters measured among groups with and without probiotic supplementation.

\section{Discussion}

Domestic waste, metallurgical activities, and industrial waste are all sources of anthropogenic metal input that result in the release of heavy metals into the environment [14]. A previous study revealed that the Brantas River in East Java contains high levels of heavy metal that exceed the government-determined threshold [2]. Many fish cultures are developed in freshwater, including rivers or reservoirs, for example, in freshwater fish cage cultivation [15]. Because fish are used primarily as food, it is necessary to consider heavy metal accumulation in aquaculture [16]. Our data showed that $\mathrm{Cu}$ was accumulated at high concentrations in the blood and testes of Nile tilapia, which can cause induction of lipid peroxidation and damage to cells and tissues.

We found that exposure to $\mathrm{Cu}$ significantly reduced the levels of $\mathrm{HBG}, \mathrm{HCT}, \mathrm{RBCs}$, and WBCs in Nile tilapia (Figure-1). The decrease in these parameters may have been due to the destruction of mature RBCs and inhibition of erythrocyte production, as well as reduction in hemosynthesis that affects hematopathology or causes acute hemolytic crises that cause anemia in fish exposed to various environmental contaminants [17]. These results are in accordance with those of Srivastava and Punia [18], who found that toxic substances in water are a source of stress for aquatic organisms and that they cause physiological dysfunction, which induces changes in the blood parameters of fish, that is, significant reductions in RBCs and HCT indicative of anemia. Exposure to $\mathrm{Cu}$ also decreases WBCs, which indicates that $\mathrm{Cu}$ negatively affects the immune system of fish. WBC function is related to mechanisms that protect against the toxic reactions caused by heavy metal accumulation.

In the present study, increasing $\mathrm{Cu}$ exposure concentrations up to $1.5 \mathrm{mg} / \mathrm{L}$ significantly decreased the GSI in Nile tilapia (Figure-2). These effects show that cellular metabolism is affected by molecules

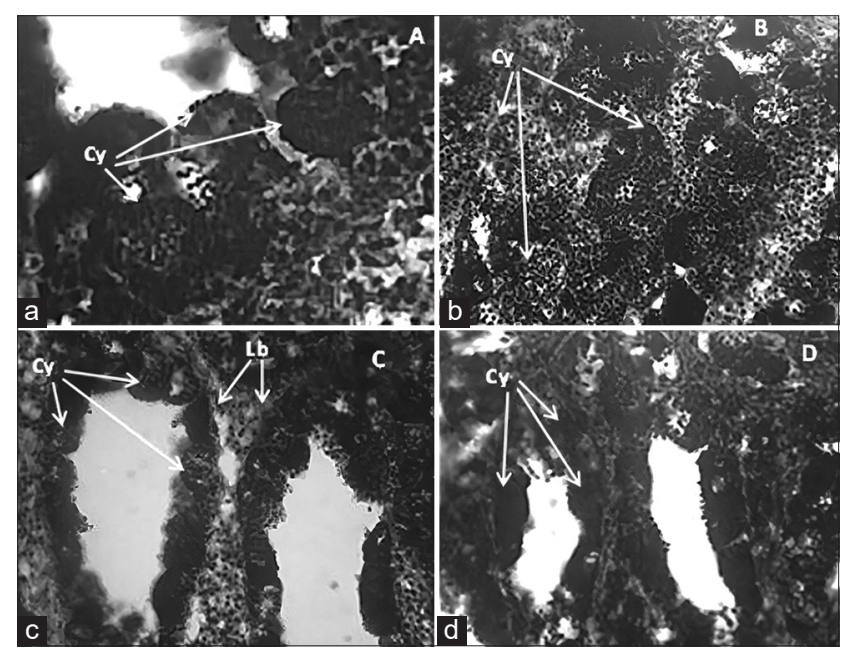

Figure-2: Photomicrographs of transverse sections of Oreochromis niloticus testes from various groups exposed to $\mathrm{Cu}$ with and without probiotic supplement. $\mathrm{a}=$ Control $(0+p) ; b=0.75 \mathrm{mg} / \mathrm{L} \mathrm{Cu} ; c=1.5 \mathrm{mg} / \mathrm{L} \mathrm{Cu} ; d=3 \mathrm{mg} / \mathrm{L} \mathrm{Cu}$. $\mathrm{Cy}=\mathrm{cyst}, \mathrm{Lb}=$ Lobulus.

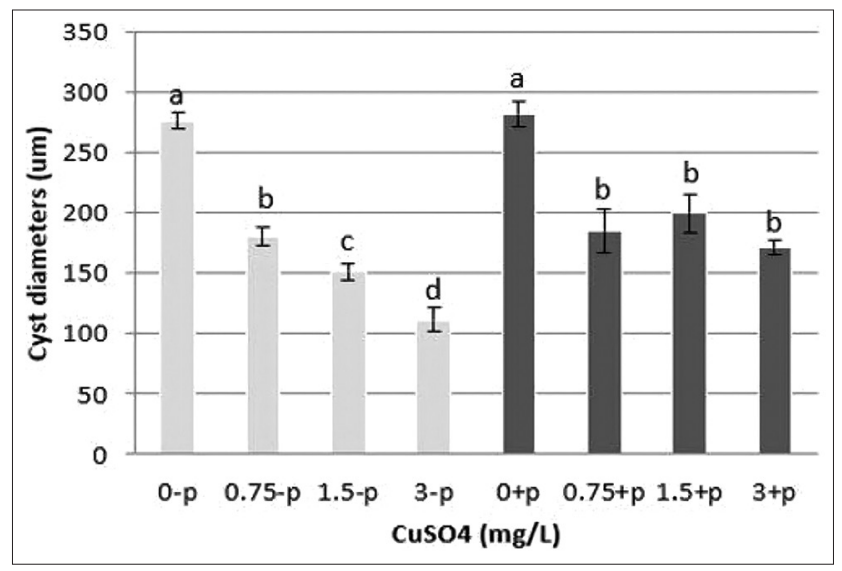

Figure-3: The diameter of cysts in the testicular lobule of Oreochromis niloticus. Values are represented as means \pm standard deviation $(n=6) . \quad p<0.05$ significantly different from control.

that cannot be taken up by cells under heavy metal pressure [19]. Our study indicated that increased metal accumulation in fish testes is due to higher concentrations of metals in the water of their habitat. A major mechanism underlying heavy metal toxicity is oxidative stress, which arises from an imbalance between the production of free radicals and antioxidant defenses in organisms. Indeed, high concentrations of ROS are known to cause cell and tissue damage [10].

Here, the MDA levels of Nile tilapia increased as $\mathrm{Cu}$ exposure concentrations increased (Figure-4). Many studies have confirmed the presence of oxidative stress caused by ROS during heavy metal metabolism in cells [20]. ROS are considered to be directly involved in oxidative damage to lipids with the final product being MDA [21]. ROS accumulation disrupts the oxidant-antioxidant balance and causes cell damage and increased mortality [22].

ROS can also change the histological structure of fish gonads, which has been widely acknowledged in 
the previous work [5]. An abundance of evidence indicates that in vivo experimental exposure of adult male fish to heavy metals has detrimental effects on their gonad, gill, and liver histology, especially in Barbodes spp. [2]. In the present study, damage to the structure of the fish testicular tubules was caused by $\mathrm{Cu}$ exposure (Figure-1). Other studies have found that exposure to pollutants can cause a decrease in GSI [23], change the structure of testicular histology [2], reduce the quality of fish spermatozoa [6], and alter reproductive behavior [24].

Our data show that probiotic supplements can ameliorate the effects of $\mathrm{Cu}$ on hematological and GSI parameters (Figures-1 and 2), as well as decrease the absorption of $\mathrm{Cu}$ and MDA in the testes (Figures-3 and 4), and prevent $\mathrm{Cu}$-induced histological damage to fish gonads (Figure-2). The protective mechanism of probiotics against heavy metal exposure generally involves binding to the heavy metal, inhibiting intestinal absorption, and protecting the intestinal barrier, which leads to reduced heavy metal accumulation, alleviation of oxidative stress, and mitigation of tissue damage [25]. Furthermore, Lactobacillus has the ability to export metals out of cells; thus, these bacteria can reduce cell and tissue damage to organisms by decreasing the cellular concentration of heavy metals. Bacterial cell walls act as a barrier against heavy metal ions; these ions bind to the peptidoglycan layer and teichoic and teichuronic acids found in cell walls. Therefore, the provision of probiotic supplements can protect against damage to fish cells and tissue during exposure to $\mathrm{Cu}$.

\section{Conclusion}

$\mathrm{Cu}$ exposure at $\geq 1.5 \mathrm{mg} / \mathrm{L}$ negatively affected the hematologic parameters and GSI of Nile tilapia while also increasing MDA levels as well as damage to testicular cells and tissue. However, probiotics supplementation in fish feed at a concentration of $25 \mathrm{~mL} / \mathrm{kg}$ feed $\left(1 \times 10^{8} \mathrm{CFU} / \mathrm{mL}\right)$ helped protect $\mathrm{HCT}$ and HBG levels during $\mathrm{Cu}$ exposure. Probiotics also helped prevent damage to fish gonads during exposure to $\mathrm{Cu}$. Therefore, probiotics based on the Lactobacillus group of bacteria were able to neutralize $\mathrm{Cu}$ toxicity in Nile tilapia.

\section{Authors' Contributions}

AH and MP: Participated in conceptualizing, designed experiments, and drafted the manuscript. $\mathrm{AH}, \mathrm{HS}$, and MP: Involved in experimentation, data collection, and data analysis. AH and MP: Involved in the preparation and revision of the manuscript. All authors read and approved the final manuscript.

\section{Acknowledgments}

The authors would like to thank the Faculty of Science and Technology, Universitas Airlangga, Indonesia, which provided funding for Superior Faculty Research Activity in 2019 (Grant no. 2427/ UN3.1.8/LT/2019).

\section{Competing Interests}

The authors declare that they have no competing interests.

\section{Publisher's Note}

Veterinary World remains neutral with regard to jurisdictional claims in published institutional affiliation.

\section{References}

1. Al-Rawi, S.M (2005) Contribution of man-made activities to the pollution of the Tigris within Mosul Area/IRAQ. Int. J. Environ. Res. Public Health, 2(2): 245-250.

2. Hayati, A., Abdizen, M.M., Antien, R.S., Solikha, B.M., Maulidyah, N., Tiantono, N., Widyana, H., Sugiharto. and Winarni, D. (2017) Bioaccumulation of heavy metals in fish (Barbodes sp.) tissues in the Brantas River, Indonesia. J. Appl. Environ. Biol. Sci., 7(3): 139-143.

3. Agah, H., Leermakers, M., Elskens, M., Fatemi, S.M.R. and Baeyens, W. (2009) Accumulation of trace metals in the muscles and liver tissues of five fish species from the Persian Gulf. Environ. Monit. Assess, 157(1-4): 499-514.

4. Afshan, S., Ali, S., Ameen, U.S., Farid, M., Bharwana, S.A., Hannan, F. and Ahmad, R. (2014) Effect of different heavy metal pollution on fish. Res. J. Chem. Environ. Sci., 2(1): 74-79.

5. Hayati, A., Pratiwi, H., Khoiriyah, I., Winarni, D. and Sugiharto. (2016) Histopathological assessment of cadmium effect on testicles and kidneys of Oreochromis niloticus in different salinity. AIP Conf. Proc., 1854(1): 1-8.

6. Hayati, A., Giarti, K., Winarsih, Y., Amin, M.F.F. (2017) The effect of cadmium on sperm quality and fertilization of Cyprinus carpio L. J. Trop. Biodivers. Biotechnol, 2(2): 45-50.

7. World Health Organization. (2001) Health and Nutritional Properties of Probiotics in Food including Powder Milk with Live Lactic Acid Bacteria. World Health Organization, Geneva.

8. Halttunen, T. (2007) Removal of Cadmium, Lead and Arsenic from Water by Lactic Acid Bacteria. Functional Foods Forum, Department of Biochemistry and Food Chemistry, University of Turkey, Turkey.

9. Gomathy, M. and Sabarinathan, K.G. (2010) Microbial mechanisms of heavy metal tolerance. Agric. Rev., 31(2): 133-138.

10. Hayati, A., Wulansari, E., Armando, D.S., Sofiyanti, A., Amin, M.H.F. and Pramudya, M. (2019) Effects of in vitro exposure of mercury on sperm quality and fertility of tropical fish Cyprinus carpio L. Egypt. J. Aquat. Res., 45(1): 189-195.

11. Håstein, T., Scarfe, A.D. and Lund, V.L. (2005) Sciencebased assessment of welfare: Aquatic animals. Rev. Sci. Tech., 24(2): 529-554.

12. Rafiee, G.R.I., Saad, C.R., Kamarudin, M.S., Ismail, M.R. and Sijam, K. (2018) Effects of supplementary nutrient in anaquaponic system for production of ornamental red tilapia (Oreochromis spp.) and lettuce (Lactuca sativavar longifolia). Int. J. Ornam. Aquat. Res., 1(1): 41-51.

13. Alkobaby, A.I. and El-Wahed, R.K.A. (2017) The acute toxicity of copper to Nile Tilapia (Oreochromis niloticus) fingerlings and its effects on gill and liver histology. J. Aquac. Res. Dev., 8(1): 465

14. Yan, X., Liu, M., Zhong, J., Guo, J. and Wu, W. (2018) How human activities affect heavy metal contamination of soil and sediment in a long-term reclaimed area of the Liaohe river delta, North China. Sustainability, 10(2): 338.

15. Filho, E.Z., Pedron, J.S. and Ribolli, J. (2018) Opportunities and challenges for fish culture in Brazilian reservoirs: A review. Acta Limnol. Bras., 30(e302): 12617. 
16. Gracia, G.G., Miguel, E.J.L., Gabriel, M.A.L. and Mingala, C.N. (2016) The corollary effect of heavy metal accumulation in freshwater ponds on the hematological profile of Nile Tilapia (Oreochromis niloticus). Environ. Exp. Bot., 14(2): 69-73.

17. Al-Asgah, N.A., Warith, A.W.A., Younis, E.S.M. and Allam, H.Y. (2015) Haematological and biochemical parameters and tissue accumulations of cadmium in Oreochromis niloticus exposed to various concentrations of cadmium chloride. Saudi J. Biol. Sci., 22(5): 543-550.

18. Srivastava, R. and Punia, P. (2011) Effect of heavy metal on biochemical and hematological parameters in Cyprinus carpio and its use as a bioindicators of pollution stress. $J$. Ecophysiol. Occup. Health., 11(1-2): 21-28.

19. Singh, S. and Srivastava, A.K. (2015) Variations in hepatosomatic index (HSI) and gonadosomatic index (GSI) in fish Heteropneustes fossilis exposed to higher sub-lethal concentration to arsenic and copper. J. Ecophysiol. Occup. Health., 15(3-4): 89-93.

20. Valko, M., Morris, H. and Cronin, M.T.D. (2005) Metals, toxicity and oxidative damage. Curr. Med. Chem., 12(10): 1161-1208.
21. Farombi, E.O., Adelowo, O.A. and Ajimoko, Y.R. (2001) Biomarkers of oxidative stress and heavy metal levels as indicators of environmental pollution in African cat fish (Clarias gariepinus) from Nigeria Ogun River. Int. J. Environ. Res. Public Health, 4(2): 158-165.

22. Morsy, A.A., Salama, K.H.A., Kamel, H.A. and Mansour, M.M.F. (2012) Effect of heavy metals on plasma membrane lipids and antioxidant enzymes of zygophyllum species. Eurasia J. Biosci, 60: 1-10.

23. Gerbron, M., Geraudie, P., Fernandes, D., Rotchell, J.M., Porte, C. and Minier, C. (2014) Evidence of altered fertility in female roach (Rutilus rutilus) from the River Seine (France). Environ. Pollut., 191: 58-62.

24. Bertram, M.G., Saaristo, M., Baumgartner, J.B., Johnstone, C.P., Allinson, M., Allinson, G. and Wong, B.B (2015). Sex in troubled waters: Widespread agricultural contaminant disrupts reproductive behavior in fish. Horm. Behav., 70: 85-91.

25. Feng, P., Ye, Z., Kakade, A., Virk, A.K., Li, X. and Liu, P. (2018) A review on gut remediation of selected environmental contaminants: Possible roles of probiotics and gut microbiota. Nutrients, 11(1): 22.

\section{$* * * * * * * *$}

